\title{
Water in Los Angeles: Rethinking the Current Strategy
}

\section{Keaton Barr ${ }^{1 *}$, Anna Goldberg ${ }^{2 *}$, Bineh Ndefru ${ }^{3 *}$, Conner S. Philson $^{4 *}$,Emily Ryznar ${ }^{4 *}$, and Regina Zweng ${ }^{4^{*}}$}

1 University of California Los Angeles, Department of Chemistry and Biochemistry, Los Angeles, CA

2University of California Los Angeles, Department of Molecular, Cell and Developmental Biology,

Los Angeles, CA

3University of California Los Angeles, Department of Materials Science and Engineering, Los Angeles, CA ${ }^{4}$ University of California Los Angeles, Department of Ecology and Evolutionary Biology, Los Angeles, CA

*All authors contributed equally

http://doi.org/10.38126/JSPG170202

Corresponding author: cphilson@ucla.edu

Keywords: water conservation; water acquisition; drought; clean water access; urban engineering

Executive Summary: Southern California has been subject to multi-year droughts that are expected to become more frequent in coming years. While only receiving $25 \%$ of the state's annual rainfall, Southern California is responsible for $80 \%$ of the state's water demand, necessitating imports from Northern California and out-of-state. Projects for local water management have been undertaken. However, a lack of funding has prevented larger sustainable water projects in Southern California from being implemented. Additionally, a large portion of the current funding is being used towards desalination projects that compromise important ecological functions and services. Given the existing technology and current political and funding landscape, we propose the implementation of urban engineering projects and greenspaces to increase local water supply and decrease the dependency on imported and unsustainable water sources. The collective approach of increasing stormwater capture through greenspaces and engineering solutions would increase equitable access to clean water and city-wide resilience for future droughts without the ecological risks and lack of equity posed by current strategies such as desalination.

\section{Introduction}

\section{i. Statement of issue}

There have been six major multi-year drought periods in California during the last 90 years, three of which have occurred during the last 19 years (California Water Science Center n.d.). With the ongoing climate crisis, it is predicted that these drought periods will become more severe and frequent as time progresses. In a relatively dry state such as California, worsening drought conditions threaten to severely affect the local water supply. This threat is compounded as Southern California makes up $80 \%$ of the state's water demand while only receiving $25 \%$ of its annual rainfall (California Department of Water Resources n.d.). Because of this disproportionate supply and demand imbalance, Los Angeles (L.A.) County and the whole of Southern California must import a majority of its water supply from the San Joaquin River Delta and the Colorado River Aqueduct, creating extra burden on these already drought prone watersheds (California Department of Water Resources n.d.; U.S. Census Bureau n.d.).

On top of an increasingly uncertain supply of water, the population of L.A. County has continued to grow in the last decade (County of Los Angeles 2019). These two factors make it imperative that L.A. County works to establish projects and enact legislation to develop a more sustainable water supply for the region. Doing so will not only create a more secure 
and sustainable local water supply, but also reduce the region's reliance on economically and environmentally costly imported water from Northern California and out-of-state sources. However, while California and L.A. County have taken many steps in recent years towards this end, the current strategy must be improved to ensure the sustainability of current water supplies and their ecosystems. Here we explore the history, current status, strategies explored to date, and propose alternative means of resolving water conservation in L.A County.

ii. Current status of alternative water source strategy Current alternative water sources in Southern California include runoff capture and desalination systems. In the 2019-2020 budget, L.A. County proposed $\$ 78.6$ million be provided for further water conservation efforts through the capture and treatment of stormwater runoff. L.A. County also proposed that $\$ 74.7$ million be provided to maintain and construct greenspaces in the interest of water conservation (California State Coastal Conservancy n.d.). Additional funding for L.A. County greenspaces is provided by the California Coastal Conservancy's L.A. Urban Greening program, an \$11.5 million multiyear program to create additional greenspaces for the purpose of collection of stormwater runoff (California Department of Water Resources 2019).

Additionally, in 2019, the California Department of Water Resources provided a $\$ 24.2$ million grant to fund desalination projects in Southern California and L.A. County for both ocean water and brackish groundwater sources. Beneficiaries of this funding were the West Basin Municipal Water District in L.A. County (for projects supplying additional local drinking water), the Southern California Edison Company (for a saltwater well, desalination facility, and storage and distribution system), and the city of Santa Monica (for reducing concentrate waste discharge in desalinated water) (Shimabuku et al. 2018).

While L.A. County has self-allocated and received significant funding from the state of California, there is still a lack of funding to fully supplement large-scale projects that provide wide-reaching and sustainable alternative water sources for L.A. County (State Water Resources Control Board Division of Water Quality 2018). L.A. County estimates that $\$ 511.3$ million will be needed over the next five years to fund development and implementation of alternative water source systems within the county (California State Coastal Conservancy n.d.). However, current sources of state funding (provided by The Water Quality, Supply, and Infrastructure Improvement Act of 2014) are insufficient to bridge the funding gap. Additionally, under the current implementation plan, L.A. County is investing heavily in desalination, which can contribute to significant environmental degradation through heavy energy usage and pollution and may result in greater long-term financial costs through daily operations (Latteman and Höpner 2008; Pierce et al. 2019). In order to create the most sustainable water future, it is imperative to concentrate L.A. County's limited financial resources into funding the most costeffective and sustainable water policy option(s).

\section{Policy options}

i. Option 1: Implementing urban engineering solutions Stormwater, or water that originates from rain, snow, and ice melt, is a cost-effective and sustainable source for augmenting water supplies. However, L.A. County currently diverts approximately 163 billion gallons of stormwater to the ocean each year (California Coastkeeper Alliance, n.d.). Urban engineering solutions can help capture stormwater and replenish local water sources in L.A. County by slowing the flow of stormwater to the ocean. Engineering solutions such as detention/retention basins, dry wells, and permeable pavement capture aid in groundwater recharge by facilitating storm water to slowly filter through permeable soil (Carrillo et al. 2016; Southern California Water Coalition 2018). Further, catchment cisterns or rain barrels capture and store stormwater for direct use in irrigation, household chores, or for other (generally) non-potable needs (Jarrett 2016).

Potable reuse of recycled wastewater is another engineering solution that can help improve L.A. County's sustainable water landscape. This involves treating wastewater (used for cleaning, washing, flushing, etc.) to a level that meets water quality standards, allowing it to be reintroduced into the potable water system after several months (Metcalf et al. 1979). Researchers from UC Davis suggest potable reuse could yield enough water to supply 8 million Californians with water annually (United 
States Environmental Protection Agency and CDM Smith 2017).

\section{Advantages}

Large-scale engineering solutions such as detention basins have the potential to capture a significant volume of stormwater runoff across multiple landuse types, and thus can help supply both local and regional water demands (Southern California Water Coalition, 2018). Retention basins, dry wells, and permeable pavement can improve water quality by filtering contaminants through permeable soil. Smallscale engineering solutions for stormwater capture such as catchment cisterns are useful in urban settings where space is limited (Southern California Water Coalition, 2018). Wastewater is created at an almost constant rate throughout the year, and thus can provide a stable and independent water source if effectively recycled (Metcalf et al. 1979).

\section{Disadvantages}

Large-scale engineering solutions for stormwater capture can be difficult to scale down to local levels, and thus may not help lessen L.A. County's dependency on non-local water sources. In contrast, scaling up small-scale engineering solutions for stormwater capture can be expensive, as existing infrastructure may need to be modified for implementation (Southern California Water Coalition 2018). Additionally, public opinion of reusing wastewater as a potable water source is not favorable due to the potential presence and long-term effects of trace quantities of drug compounds, hormones, and personal care products in recycled wastewater.

The process of recycling wastewater is also expensive. For example, a wastewater reclamation facility in Orange County had approximately $\$ 480$ million in startup costs and required $\$ 29$ million a year to operate (Englande et al. 2015), and the lifetime costs of such facilities can range from $\$ 0.23-\$ 0.70$ per 1,000 liters (The National Academies 2012). This contrasts large-scale stormwater capture projects that can have estimated lifetime costs ranging from $\$ 0.05$ - $\$ 0.24$ per 1,000 liters (The National Academies 2016).

\section{ii. Option 2: Increasing use of greenspace for water capture}

Parks and other greenspaces are excellent places to capture stormwater for public use or groundwater recharge (Pennsylvania Department of

Environmental Protection 2019). Existing parks can be improved by adding rain gardens, which are shallow surface depressions filled with native vegetation (Stratus Consulting Inc. 2009). Vegetation facilitates water retention, infiltration, and serves as a natural filter for pollutants. Vegetation can also reduce runoff, helping reduce costs of stormwater treatment. Aboveground vegetated channels that collect, and transport stormwater are another solution which will outperform traditional underground pipes, which only transport water, by naturally filtering water and preserving natural vegetation. Other options to improve natural water sources include restoration of riverbanks, floodplains, and wetlands (Stratus Consulting. 2009).

\section{Advantages}

Increases in the amount of green spaces and investment in the restoration of wetlands would provide alternative benefits that extend beyond the natural capture and filtration of water. These include an increase in recreation and aesthetic value, improved public health and safety, wildlife habitat and corridors, carbon sequestration, a reduction of air and water pollutants, and urban cooling (Tenne et al. 2013). These non-water benefits also increase opportunities for partnerships with local agencies and increase funding opportunities due to the prioritization of funding for projects with far reaching benefits (Southern California Water Coalition 2018; Carrillo et al. 2016).

\section{Disadvantages}

Smaller scale, decentralized projects such as rain gardens or parks can be difficult and expensive to scale up, due to land constrictions and water transportation logistics, and have smaller capture volumes than larger engineering projects (such as spreading basins) (Carrillo et al. 2016).

\section{iii. Option 3: Expansion of desalination projects}

Desalination has been suggested as a solution in regions where seawater is available, but freshwater is scarce. Modern technologies exist to remove salt, biological, and other materials that render brackish water and seawater unsafe for human use. The most common process is called reverse osmosis, where contaminated water is forced through a semipermeable membrane that removes contaminants while allowing clean water to emerge. 


\section{Advantages}

The foremost advantage of reverse osmosis is its degree of efficacy, producing reliably clean and potable water that can be used for a variety of human needs (Ghaffour et al. 2015). Use of seawater and brackish water sources also reduces our reliance on freshwater supplies, allowing the conservation of these systems and their watersheds, as well as the animals and plants that rely on them (Karagiannis and Soldatos 2008). Unlike natural freshwater, seawater provides a reliable and almost inexhaustible source of water, even in times of drought and changing environmental factors.

\section{Disadvantages}

While effective, desalination is an extremely expensive process and poses ecological risks. Cost estimates place the production of 1,000 liters of clean water between $\$ 0.5$ and $\$ 3.25$, around a two-fold increase in cost compared to groundwater and capture systems (Alkaisi et al. 2017; Ghaffour et al. 2013). For the L.A. Metropolitan Area, this would cost between $\$ 6.5$ and $\$ 42.6$ million/day, given current population and per capita water use estimates (County of Los Angeles 2019). A recent study on a proposed desalination plant in Orange county found a moderate to severe increase in projected costs of water for desalinated water $(\$ 0.67-\$ 1.62$ per 1,000 liters) compared to alternative water sources $(\$ 0.69$ per 1,000 liters) (Pierce et al. 2019). A majority of these costs are attributable to the extreme energy demands of desalination (Latteman and Höpner 2008). This energy consumption will also further drive greenhouse gas emissions, worsening global climate change and the subsequent problems already facing water-stricken locations around the world (Karagiannis and Soldatos 2008; Ghaffour et al. 2015).

A potential ecological impact is the impingement and entrainment of marine organisms. This is when marine organisms are caught in the seawater intake and killed during the process of desalination. Some of this can be prevented by decreasing the mesh size at the point of intake, but some organisms such as fish eggs and plankton cannot be easily filtered out (Missimer et al 2018). The byproduct of desalination is also extremely polluted, killing wildlife and vegetation which come in contact with it, contaminating freshwater sources via salt intrusion, and further degrading natural systems and watersheds (Latteman and Höpner 2008). While there is regulation around the disposal of desalination byproduct, no one mechanism has fully prevented pollution and environmental harm. In all, the efficacy benefits of desalination do not outweigh its cost and environmental disadvantages.

\section{Conclusions and recommendations}

Safeguarding California against drought is a crucial step in protecting the state against the harsh realities of climate change and we should be taking drastic measures to achieve a safe water future for the region. To effectively conserve the natural freshwater L.A. currently relies on, we recommend the expansion of urban engineering solutions and development of greenspace, while reducing the development of desalination projects. This collective approach would harness the benefits of both options while counteracting a majority of each option's disadvantages by avoiding large facilities in favor of many smaller localized facilities. Additionally, by limiting the investment into desalination we would avoid the most extreme ecological downsides and contributions to greenhouse gas emissions accompanying these current options. Lastly, by playing off the current political and funding landscape, this collective approach creates the greatest potential for natural water conservation and clean water acquisition for L.A., while also keeping the costs associated with new land acquisition and infrastructure development at a minimum.

To successfully implement these options, we recommend that L.A. County use the Clean Water State Revolving Fund (CWSRF), a Clean Water Act federal-state partnership that authorizes financial assistance for clean water projects. Another possible funding source is the Proposition 68 Implementation Grant SGM, which will provide at least $\$ 88$ million for drought and groundwater investments by the year 2022. Additionally, the recent passage of SB 231 defines "sewers" in a way that could allow cities to finance stormwater capture infrastructure projects with fewer hurdles. However, the fight to create a secure water future for California will be an ongoing challenge. Therefore, while taking full advantage of current policies and funding sources in the implementation of cost effective, ecologically friendly water projects is crucial in the present, the continued development and proper use of funding sources like 
those mentioned here will be equally important for the future of California.

\section{References}

Alkaisi, Ahmed, Ruth Mossad, and Ahmad SharifianBarforoush. 2017. "A Review of the Water Desalination Systems Integrated with Renewable Energy" Energy Procedia 110:268-274. https://doi.org/10.1016/i.egypro.2017.03.138

California Department of Water Resources. 2019. “\$24.2 Million Awarded in Grant Funding for Water Desalination Projects". California Department of Water Resources. Government of California, December 6, 2019. Retrieved 15 April 2020. https://water.ca.gov/News/Blog/2019/Decembe $\underline{\mathrm{r}-19 / \text { Grant-funding-water-desalination }}$

California Department of Water Resources. "State Water Project". The California Water System. California Department of Water Resources. Retrieved 15 April 2020. https://water.ca.gov/Programs/State-WaterProject

California State Coastal Conservancy. "Urban Greening". California State Coastal Conservancy. Government of California. Retrieved 15 April 2020. https://scc.ca.gov/projects/urban-greening/

California Water Science Center. "2012-2016 California Drought: Historical Perspective". California Drought. USGS California Water Science Center. $\begin{array}{llll}\text { Retrieved } & 15 & \text { April }\end{array}$ https://ca.water.usgs.gov/californiadrought/california-drought-comparisons.html

Carrillo, Carlos, Anna Constantino, Carrie Crane, Mathew Danielczyk, Danielle Duncan, Andrew Edstrom, Russell Frink, et al. 2016. "Sustainable Water Strategies for California". Water Education Foundation, November 2016.

County of Los Angeles. 2019. "2019-20 Budget". Los Angeles: County of Los Angeles Board of Supervisors, pp. 10, 15, 22.

Englande, A.J., Peter Krenkel, and J. Shamas. 2015. "Wastewater Treatment and Water Reclamation". Reference Module in Earth Systems and Environmental Sciences. https://doi.org/10.1016/B978-0-12-4095489.09508-7

Ghaffour, Noreddine, Jochen Bundschuh, Hacene Mahmoudi, and Mattheus M.F. Goosen. 2015. "Renewable Energy-driven Desalination Technologies: A Comprehensive Review on Challenges and Potential Applications of Integrated Systems". Desalination 356:94-114. https://doi.org/10.1016/i.desal.2014.10.024

Ghaffour, Noreddine, Thomas M. Missimer, and Gary L. Amy. 2013. "Technical Review and Evaluation of the Economics of Water Desalination: Current and
Future Challenges for Better Water Supply Sustainability" Desalination 309:197-207. https://doi.org/10.1016/i.desal.2012.10.015

Jarret, Albert. 2016. "Cisterns for capturing and reusing stormwater". Penn State Extension. May 24, 2016. https://extension.psu.edu/cisterns-forcapturing-and-reusing-stormwater

Karagiannis, Ioannis C., and Petros G. Soldatos. 2008. "Water Desalination Cost Literature: Review and Assessment". Desalination 223(1-3):448-456. https://doi.org/10.1016/i.desal.2007.02.071

Land Studies. "Parks can Play a Major Role in Managing Stormwater". Land Studies. Retrieved 15 April 2020. https://landstudies.com/parks-can-playmajor-role-managing-stormwater/

Lattemann, Sabine, and Thomas Höpner. 2008. "Environmental Impact and Impact Assessment of Seawater Desalination". Desalination 220:1-15. https://doi.org/10.1016/i.desal.2007.03.009

Metcalf L, HP Eddy, and George Tchobanoglous. 1979. Wastewater Engineering: Treatment, Disposal, and Reuse. New York, New York: McGraw-Hill.

Missimer, Thomas M., and Robert G. Maliva. 2018. "Environmental Issues in Seawater Reverse Osmosis Desalination: Intakes and Outfalls." Desalination 434 (July 2017): 198-215. https://doi.org/10.1016/i.desal.2017.07.012.

Pennsylvania Department of Environmental Protection. 2019. “Top 10 Stormwater Best Management Practices for Parks". Pennsylvania Department of Environmental Protection.

Pierce, Gregory, Nicholas Chow, Kyr a Gmoser-Daskalakis, Peter Roquemore, and Nichole Heil. 2019. "Analyzing Southern California Supply Investments from a Human Right to Water Perspective The Proposed Poseidon Ocean Water Desalination Plant in Orange County." UCLA Luskin Center for Innovation. Retrieved from https://innovation.luskin.ucla.edu/wp-content/ uploads/2019/04/Analyzing Southern CA Suppl $\mathrm{y}$ Investments from a Human Right to Water $\mathrm{P}$ erspective.pdf

Shimabuku, Morgan, Sarah Diringer, and Heather Cooley. 2018. "Stormwater Capture in California: Innovative Policies and Funding Opportunities". Pacific Institute, June 2018.

Southern California Water Coalition. 2018. "Stormwater Capture Enhancing Recharge and Direct Use through Data Collection". Southern California Water Coalition 2018 whitepaper update, April 2018.

State Water Resources Control Board Division of Water Quality. 2018. "Strategy to Optimize Resource 
Management of Stormwater". Office of Water Programs, California State University, pp. 2, 49, 50, April 2018.
Stratus Consulting Inc. 2009. "A Triple Bottom Line Assessment of Traditional and Green Infrastructure Options for Controlling CSO Events in Philadelphia's Watersheds". Stratus Consulting Inc., August 2009.

Tenne, A, D Hoffman, and E Levi. 2013. "Quantifying the Actual Benefits of Large-scale Seawater Desalination in Israel". Desalination and Water Treatment 51(1-3):26-37. https://doi.org/10.1080/19443994.2012.69504 $\underline{7}$

The National Academies of Sciences, Engineering, and Medicine Water Science and Technology Board. 2016. Using Graywater and Stormwater to Enhance Local Water Supplies. Washington, DC: The National Academies Press. https://doi.org/10.17226/21866

The National Academies of Sciences, Engineering, and Medicine Water Science and Technology Board. 2012. Water Reuse: Potential for Expanding the Nation's Water Supply through Reuse of Municipal Wastewater. Washington, DC: The National Academies Press. https://www.nap.edu/read/13303/chapter/1

U.S. Census Bureau. "U.S. Census Bureau QuickFacts". U.S. Census Bureau. Retrieved 15 April 2020. https://www.census.gov/quickfacts/fact/table/ US/PST045219

United States Environmental Protection Agency and CDM Smith. 2017. "2017 Potable Reuse Compendium". United

Keaton Barr is a Ph.D. Candidate in Biochemistry, Molecular, and Structural Biology at UCLA. He is currently studying various aspects of transcriptional regulation, primarily focusing on degradation of RNAs and transcriptional roadblocks. Keaton hopes to have a career advocating for good science and science/data literacy to both the general populace and policy makers.

Anna Goldberg is a third-year Molecular, Cell, and Developmental Biology undergraduate student at UCLA. She is an academic engagement officer for The Science Policy Group at UCLA and has aspirations for a career in environmental or healthcare-related law.

Bineh Ndefru is a Ph.D. Student in Materials Science and Engineering at UCLA. She is a part of the Institute for Risk Sciences studying technology approaches to building sustainable, reliable, and resilient nextgeneration energy systems. Bineh is interested in problems at the interface of technology and society and wishes to pursue a career developing science-informed policy solutions that effectively address social issues.

Conner S. Philson is a Ph.D. Student in Ecology and Evolutionary Biology at UCLA studying the evolution and consequences of social behavior using the yellow-bellied marmot population at the Rocky Mountain Biological Laboratory (RMBL) in Colorado. He is the External Vice President for The Science Policy Group at UCLA and the Director of Community Partnerships for UCLA's Graduate Student Association. He plans to pursue a career in science policy to advise, create, and maintain national and international policy and diplomatic relationships. 
Emily Ryznar is a Ph.D. Candidate in Ecology and Evolutionary Biology at UCLA. She currently studies mechanisms facilitating the success of species invasions, focusing on the invasion of the marine alga, Sargassum horneri, in Southern California and Baja Mexico. Emily is interested in a career that bridges applied, primary research and policy to address salient issues in conservation.

Regina Zweng received an MS in Biology studying the impacts of ocean acidification on marine algae in coral reefs. She is currently a Ph.D. Candidate in Ecology and Evolutionary Biology at UCLA and studies the impacts of eutrophication on carbonate chemistry in estuaries. She hopes to pursue a career in advocating for science-based solutions to improve public health and conservation.

\section{Acknowledgements}

We thank members of The Science Policy Group at UCLA for support throughout the creation of this manuscript. 